\title{
Total rewards that retain: A study of demographic preferences
}

\begin{tabular}{|c|c|}
\hline \multicolumn{2}{|c|}{$\begin{array}{l}\text { Authors: } \\
\text { Monica Pregnolato }^{1} \\
\text { Mark H.R. Bussin }{ }^{2} \\
\text { Anton F. Schlechter }^{1}\end{array}$} \\
\hline \multicolumn{2}{|c|}{$\begin{array}{l}\text { Affiliations: } \\
{ }^{1} \text { School of Management } \\
\text { Studies, Organisational } \\
\text { Psychology, University of } \\
\text { Cape Town, South Africa }\end{array}$} \\
\hline \multicolumn{2}{|c|}{$\begin{array}{l}{ }^{2} \text { Department of Industrial } \\
\text { Psychology and People } \\
\text { Management, University of } \\
\text { Johannesburg, South Africa }\end{array}$} \\
\hline \multicolumn{2}{|c|}{$\begin{array}{l}\text { Corresponding author: } \\
\text { Mark Bussin, } \\
\text { drbussin@mweb.co.za }\end{array}$} \\
\hline \multicolumn{2}{|c|}{$\begin{array}{l}\text { Dates: } \\
\text { Received: } 01 \text { Mar. } 2016 \\
\text { Accepted: } 21 \text { Oct. } 2016 \\
\text { Published: } 30 \text { Jan. } 2017\end{array}$} \\
\hline \multicolumn{2}{|c|}{$\begin{array}{l}\text { How to cite this article: } \\
\text { Pregnolato, M., Bussin, } \\
\text { M.H.R., \& Schlechter, A.F. } \\
\text { (2017). Total rewards that } \\
\text { retain: A study of } \\
\text { demographic preferences. } \\
\text { SA Journal of Human } \\
\text { Resource Management/ } \\
\text { SA Tydskrif vir } \\
\text { Menslikehulpbronbestuur, 15, } \\
\text { a804. https://doi. } \\
\text { org/10.4102/sajhrm.v15.804 }\end{array}$} \\
\hline \multicolumn{2}{|c|}{$\begin{array}{l}\text { Copyright: } \\
\text { (C) 2017. The Authors. } \\
\text { Licensee: AOSIS. This work } \\
\text { is licensed under the } \\
\text { Creative Commons } \\
\text { Attribution License. }\end{array}$} \\
\hline \multicolumn{2}{|l|}{ Read online: } \\
\hline 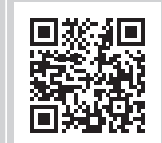 & $\begin{array}{l}\text { Scan this QR } \\
\text { code with your } \\
\text { smart phone or } \\
\text { mobile device } \\
\text { to read online. }\end{array}$ \\
\hline
\end{tabular}

Orientation: Changing workplace demographics and a dearth of employees with scarce skills have forced employers to better understand the various factors that retain talented employees.

Research purpose: In this empirical study, the reward preferences and ideal combination of total reward elements (based on an estimation of their relative importance) that retain employees from various demographic groups, including employees of different race, gender and age groups, were investigated.

Motivation for study: Organisations are competing for talented employees and to benefit from the value these individuals add, it is required of them to stay at the respective businesses. Previous studies have indicated that employees who are offered a reward package that is aligned to their personal preferences are prone to stay longer at the organisation and to be more engaged at work. However, new and novel ways need to be found to identify the reward preferences of employees.

Research design, approach and method: A quantitative approach and descriptive research design was employed to estimate the individual reward preferences and identify an ideal mix of total reward elements that retain different cohorts of employees. Three questionnaires were distributed, including a Remuneration Managers Questionnaire $(n=7)$, a Remuneration Preference Questionnaire $(n=368)$ and a Choice-based Conjoint Task Questionnaire $(n=368)$. The latter two questionnaires were distributed as an online questionnaire to South African businesses and consisted of eight choice-based conjoint tasks, as well as a field survey.

Main findings: The results of the choice-based conjoint analysis revealed that all respondents considered financial rewards (Benefits, Performance and Recognition, Remuneration, Career, in that order) as relatively speaking, the most important components in their total rewards package that would lead to their retention. For most demographic groups, the remaining three places (i.e. ranked) were Career Advancement, Learning and Work-life balance. Work-life balance was found to be relatively more important for Generation $Y$ than career advancement. For those employees with only a matric qualification and those in non-managerial positions, access to learning opportunities were the least important in their retention.

Practical/managerial implications: Human Resource managers and line managers should note that reward elements should be chosen and offered as total reward packages in such a way as to best be able to attract, engage and retain talented employees.

Contribution/value-add: The findings of the present study adds value in a sense that it assists organisations in creating customised reward packages that best suit the needs of both employees and them as employers. Providing a more ideal or preferential combination of reward elements can, by increasing retention and engagement, provide a competitive advantage for organisations.

\section{Introduction}

\section{Key focus of the study}

Employee engagement and retention are overwhelmingly cited by the Chief Executive Officers of some of the largest and fastest growing companies, as the number one priority on the Human Resource or Human Capital agenda (Frank, Finnegan \& Taylor, 2004; Schlechter, Faught \& Bussin, 2014). Business strategies, products and services can often be replicated, but it is nearly impossible to replicate a company's talent pool, a fundamental aspect whereby a business distinguishes itself from its competitors (Jensen, McMullen \& Stark, 2007).

\section{Background of the study}

The turnover of critical or key staff members, often referred to as talent, is associated with significant direct and indirect costs to an organisation. These costs include, for example, the costs associated 
with recruitment and selection, as well as intangible costs such as the loss of productivity, quality shortfalls, poor morale among the remaining employees, negative impact on customers/clients and loss of organisational knowledge when employees leave (Krishnan, 2009). The tangible and intangible costs to the company are estimated to be higher than the annual salary of a departing employee (Corporate Leadership Council, 2004). For such reasons, the retention of human capital or human resources has become a business imperative, in terms of running a successful and sustainable business.

To succeed in the so-called war for talent, employers need to have a clear understanding of how various reward factors influence whether talented employees choose to stay or leave an organisation (Dibble as cited in Kotze \& Roodt, 2005). Cohorts of employees, such as those coming from diverse demographic groups, have different expectations and demands of their work environment. As a result, a one-size-fits-all retention strategy has proven not to be effective (Bussin, 2012). The primary research question in the present study was 'What is the ideal total reward mix of reward elements that will retain skilled employees from specific demographic groups?'

\section{Trends from the research literature}

The successful retention of human capital in the global workplace has been affected by extensive changes in workforce demographics, as organisations are required to manage more diverse groups of talent pools (Snelgar, Renard \& Venter, 2013). In the United States, growing numbers of ethnic minorities are entering the labour market. In the South African context, the Employment Equity Act (No. 55 of 1998) has been instrumental in changing the demographic profile of the local labour market. South African businesses act, or should act, as catalysts for developing equity employees who were under-developed during the apartheid era (Maisela, 2001; Nzukuma \& Bussin, 2011; Tucker, Kao \& Verma, 2005). The transformation of the workforce is therefore high on the agenda in South African organisations. The dearth of black talent and the resulting competition between companies to attract such individuals as necessitated by redress legislation, adds a further dimension to the retention challenge within the South African context.

The notion that organisations should develop relevant and targeted reward packages and retention strategies to best suit multiple needs, across different demographic cohorts (e.g. generations, genders or race groups), has been the focus of research over the last few years (Codrington, 2008; Schlechter et al., 2014; Snelgar et al., 2013; Sutherland, 2004). Within the South African context, it has been found that specific reward strategies are related to the retention of Generation $X$, female employees and black professionals (Bussin \& Toerien, 2015; Kotze \& Roodt's, 2005; Krishnan, 2009; Masibigiri \& Nienaber, 2011; Schlechter et al., 2014).

\section{Research objectives}

The present study had two main research objectives: (1) to develop a better understanding of the total reward preferences within a South African business context; and (2) to identify the ideal or most desirable mix of total reward elements or total reward packages that would specifically retain employees from various demographic groupings.

\section{The potential value-add of study}

The findings of the present study contribute to the literature on reward preference. The findings have relevance and are important for workplaces, given the scarcity of skills and high competitiveness among companies in needing to retain such employees. Organisations will hopefully benefit from the findings of this study by using the results to customise reward packages in such a manner that they are based on demographic preferences and so allow them to more effectively retain key employees.

\section{What will follow}

The following literature review indicates different reward types from which the framework of the study was developed. Furthermore, the reward preferences for different race, age and gender groups are described. After this, the research method is explained and the results illustrated. The article concludes with a discussion of these results and the practical suggestions/recommendations that follow from these.

\section{Literature review}

A total rewards model that involves the integration of five key elements that attract, motivate and retain the talent required to achieve desired business results and lead to employee job satisfaction and engagement namely was developed by WorldatWork (2007) and comprises the following elements:

- Remuneration: cash provided by an employer to an employee for services rendered.

- Benefits remuneration: programmes that an employer uses to supplement the cash remuneration an employee receives. These satisfy protection needs.

- Work-life balance: organisational practices, policies and programmes as well as a philosophy that actively supports an employee's efforts to be successful within and outside the workplace.

- Performance and recognition: involves the alignment and subsequent assessment of organisational, team and individual efforts towards the achievement of business goals and organisational success. Recognition gives special attention to employee action, efforts, behaviour and performance.

- Development and career opportunities: comprises learning experiences designed to enhance employee skills and competencies. Career opportunities involve plans to help employees pursue their career goals. These are relational needs that bind workers more effectively to an organisation as they satisfy individual's needs such as personal development and fulfilment.

Pay (compensation or remuneration) is the most commonly cited reward element used in retention strategies 
(Bussin, Nicholls \& Nienaber, 2016). In reality though, pay has been found to be the fifth most common reason for leaving an organisation (Bussin, 2012). The most important rewards that retained talented workers from the fields of science, technology, financial services and information technology were financial rewards, recognition and developmental opportunities (Bussin \& Toerien, 2015; Kinnear \& Sutherland, 2000). These findings were corroborated by De Vos and Meganck (2008); Horwitz, Heng and Quazi (2003); Horwitz et al. (2006) as well Sutherland and Jordaan (2004). In a study of employees in South Africa and Singapore, it was found that employees were retained most effectively when provided with challenging assignments and fulfilling work, as well as incentive and performance bonuses (Horwitz et al., 2006). Others found that reward elements relating to personal comfort including medical aid benefits, social relations at work, pension and contractual obligations did not retain employees (Sutherland \& Jordaan, 2004; Van Rooy \& Bussin, 2014). The lack of value placed on traditional retention strategies such as work-life balance practices, for example, extra vacation time, childcare facilities or teambuilding exercises was reported by Birt, Wallis and Wintermitz (2004).

\section{Rewards that retain employees of different races}

Limited social science and business literature exists in South Africa to indicate the mix of total rewards that retain previously disadvantaged individuals (PDIs), as described in the Employment Equity Act (No. 55 of 1998). Black professionals considered work environments with strong Employment Equity (EE) initiatives and diverse work groups as key retention factors (Maisela, 2001). In a study of demographic differences in retention factors affecting managerial and specialist bank staff indicated that PDIs rated performance standards, diversity, competitive remuneration and employer of choice perception as rewards that were less likely to retain them, than non-PDIs (Kotze \& Roodt, 2005). In a study of black professionals, it was noted that this group was more likely to remain in their current job because they valued the work they were engaged in rather than the company they worked for (Booysen, 2007; Khanyile \& Mapongo, 2007; Mmolaeng \& Bussin, 2012).

\section{Rewards that retain different genders}

In South Africa, women are classified as equity candidates under the Employment Equity Act (No. 55 of 1998). Limited literature exists both in South Africa and internationally to indicate the reward elements that specifically retain female employees. A study that investigated the career paths of women who had left organisations discovered that in $51 \%$ of the cases women joined rival organisations in more prestigious positions (Krishnan, 2009).

\section{Rewards that retain employees of different age groups}

Generation is a term used to refer to people born in the same general time span and who share historical or social life experiences. Because of similar life experiences, each generation develops a unique personality that determines their feelings towards authority and organisation. This generational personality also is thought to influence what individuals expect from their employer and how they intend to satisfy such needs (Bussin, 2012; Gursoy, Maier \& Chi, 2008; Snelgar et al., 2013; Towers Perrin, 2003).

In South Africa, experienced non-PDI employees aged 50+ will be exiting the labour market over the next 10 years, leaving a large skills gap, which the current education system is failing to address (D'Amato \& Herzfeldt, 2008). This has created a situation where employers need to ensure that they can grow and retain their young talent, even though this is becoming an increasingly difficult task with skilled professionals of all races increasingly choosing to frequently change jobs in an effort to satisfy their need for quick career development and progression (Nzukuma \& Bussin, 2011; Temkin, 2008; Van Rooy \& Bussin, 2014).

According to a study conducted by Towers Perrin (2003), employees aged between 18 and 29 typically value base salary, variable pay and company shares the most, while employees aged between 30 and 44 typically value medical aid, base salary and deferred remuneration. Employees aged between 45 and 54 are thought to view base salary, deferred remuneration and retirement funding as important while employees of 55 years or older value retirement funding and base salary equally together with medical aid.

Baby Boomers (those born between 1946 and 1964) make up a sizeable portion of the current workforce and have extensive knowledge and business experience. Literature indicates that this generation is retained by benefits programmes such as medical aid and retirement benefits and initiatives to assist in preparing for their retirement (Tiku, 2007). These findings are supported by Wallace (2006) in a study of generational differences across the legal profession where pay was deemed to be more important to Baby Boomers than to Generation X'ers (those born between 1965 and 1980). Instead, Generation X and Generation Y (those born between 1981 and 2000) employees are believed to be more independent and selfreliant than Baby Boomers; they are likely to have multiple careers; are prepared to make rapid career transitions and leave an organisation when their needs are not being met; and emphasise work-life balance (D'Amato \& Herzfeldt, 2008).

The most successful reward elements to retain Generation $X$ employees include the offer of career development opportunities, including jobs that aid this generation in advancing to the next job, career ladders and providing challenging assignments (D'Amato \& Herzfeldt, 2008; Smit, Stanz \& Bussin, 2015). These rewards are in alignment with this generation's need to be loyal to their own skills as opposed to a particular company. A focus group study of Generation $X^{\prime}$ ers highlighted their need to leave work at work, as well as trying to strike a balance in their lives (Gursoy et al., 2008). These findings were supported in a study where work-life programmes such as sabbaticals and flexitime were popular 
among Generation X'ers (Gabriel, 1999). Work-life balance and flexibility options such as flexitime, encouraging the use of online social networks like Facebook and Twitter or flexi office are seen as ways to satisfy the Generation Y's need for loyalty to their lifestyle rather than their job (Roy, 2008).

Therefore, the current study has two main research questions that it aims to address: what is the mix and the desired amount of total rewards that retain employees from various demographic groups, which - in the context of the current study - refers to knowledge workers and employees from different race, gender and age groups. The second question is what elements of total rewards do employees deem important in their retention.

\section{Research design Research approach}

A descriptive research design, following a quantitative approach was employed to address the research objectives.

\section{Research method}

Six total reward elements were identified using the WorldatWork Total Rewards model (2007). Even though the model suggests five reward elements, it was decided to split training and development (learning) opportunities from career advancement. These reward elements were identified as commonly applicable in many large organisations according to a Remchannel South African Benefits Guide survey (2007). A field survey and choice-based conjoint analysis, also referred to as choice-based modelling, was used to investigate the relative importance of the reward elements in retaining employees of different demographic groups.

Rather than asking survey respondents directly what attributes they find most important (as is done in the field survey), conjoint analysis utilises a more realistic context of respondents evaluating potential profiles. Conjoint analysis is based on the assumption that individuals perceive products, reward packages in this instance, as consisting of a number of attributes (each with levels) that each offer a measure of worth or value or utility. Conjoint analysis identifies the relative worth of each of the attributes making up a product or service or concept in order to find the offering or combination that contains the most desirable constellation of attributes. This method replicates real-life decision making in that individuals cannot obtain everything that they desire and have to psychologically make trade-offs between various combinations, unlike typical survey approaches were items are considered one at a time (i.e. can obtain everything that they desire).

\section{Measuring instruments}

\section{Questionnaire 1: Remuneration Managers Questionnaire}

The purpose of the first questionnaire was to receive expert input from remuneration managers as to the reward package they would construct to retain three hypothetical employees, namely Employee A - someone with critical skills, Employee
B - someone with technical skills and Employee C - someone who is not considered key talent and readily replaceable. Employee A was classified as scarce talent and thought to pose a high retention risk to the company were they to resign. Employee B was considered to pose a moderate retention risk. Employee $\mathrm{C}$ was not considered key talent.

Employee $C$ was considered to be the recipient of the lowest level of rewards and would equate to level 3 (low) in the choice-based conjoint task. Employee A, the recipient of the highest level of rewards, would equate to level 1 (high) and Employee B to the intermediate level or level 2 (medium) in setting up the choice-based conjoint tasks.

\section{Questionnaire 2: Total Rewards Preference Questionnaire}

A second questionnaire was developed and was based on the WorldatWork Total Rewards model (2007). This scale was designed to measure which total rewards respondents deemed most important in deciding whether to stay or leave their current organisation. Responses were recorded on a 5-point Likert-type scale where 1 represented 'Not at all important' and 5 indicated 'Very Important'. The scale comprised 20 questions covering 6 total rewards namely: (1) Performance and recognition, (2) Work-life balance, (3) Learning, (4) Career advancement, (5) Remuneration and (6) Benefits.

\section{Questionnaire 3: Choice-Based Conjoint Task Questionnaire}

The third questionnaire comprised computer-generated conjoint tasks. Each conjoint task is a random combination of the various levels of the reward elements (attributes). This was used to assess employee preferences by determining the relative importance of reward elements (by calculating part-worths).

\section{Research procedure}

Before administration, ethics clearance was obtained and the online questionnaire piloted on a small group of employees who are members of South African Reward Association (SARA). The survey was amended using the results from the pilot group. The survey was completed online and respondents were given 3 weeks to do so. An email reminding the employees of the closing date was sent after the first week to encourage participation.

\section{Research participants}

A non-probability sampling method, namely convenience sampling, was employed throughout.

\section{Descriptive statistics for demographic characteristics of the respondents}

Questionnaire 1: The first questionnaire was circulated to 15 remuneration managers across a variety of industries in South Africa and seven usable responses were received (47\% response rate). The majority $(86 \%)$ of the companies represented by them were from the private sector, while the remaining $14 \%$ were from the Government or Quasi Government Sectors. 
Questionnaires 2 and 3: The second and third questionnaires were distributed within a multinational oil company based in Cape Town, as well as companies who are Corporate Members of the SARA. Approximately 600 of the second and third questionnaires were distributed and 361 usable responses were received, representing a $60 \%$ response rate. Adescription of the demographic composition of the realised sample for the second and third questionnaires is provided in Table 1.

The majority of respondents (56\%) were women, and these results are considered typical of the gender demographics of the South African workplace. The sample consisted of predominantly white respondents (54.3\%) with African and mixed race groups, collectively, having nearly equal representation. The majority of the sample $(79 \%)$ were 31 years and older. Eighty-six percent of the sample had obtained a post matric qualification. The single largest groupings of respondents $(36.6 \%)$ were in non-managerial roles with the majority operating in individual contributor or specialist roles. For the purposes of analysis, the following groups were combined to ensure a more balanced sample: Mixed race and Indians were combined into African under the race group sample (i.e. creating more balanced black and white respondent groups). Education level was revised to reflect the education classifications of Degree (3 years) and Diploma as Undergraduate-level qualification, while Honour's, Master's and Doctorates were reclassified as Postgraduate-level

\begin{tabular}{|c|c|c|}
\hline Demographic characteristic & Frequency & Percentage \\
\hline \multicolumn{3}{|l|}{ Gender } \\
\hline Female & 202 & 56.0 \\
\hline Male & 159 & 44.0 \\
\hline \multicolumn{3}{|l|}{ Racial classification } \\
\hline African & 60 & 16.6 \\
\hline Mixed race & 62 & 17.2 \\
\hline Indian & 35 & 9.7 \\
\hline White & 196 & 54.3 \\
\hline Prefer not to disclose & 8 & 2.2 \\
\hline \multicolumn{3}{|l|}{ Age groups } \\
\hline $21-30$ & 74 & 20.5 \\
\hline $31-40$ & 132 & 36.6 \\
\hline $41-50$ & 107 & 29.6 \\
\hline $51-60$ & 45 & 12.5 \\
\hline $61-65$ & 3 & 0.8 \\
\hline \multicolumn{3}{|l|}{ Education level } \\
\hline Matric & 51 & 14.1 \\
\hline Diploma & 55 & 15.2 \\
\hline Degree (3 years) & 97 & 26.9 \\
\hline $\begin{array}{l}\text { Honours (4th year first } \\
\text { Postgraduate qualification) }\end{array}$ & 108 & 29.9 \\
\hline Masters & 47 & 13.0 \\
\hline Doctorate & 1 & 0.3 \\
\hline Not applicable & 2 & 0.6 \\
\hline \multicolumn{3}{|l|}{ Job level } \\
\hline Non-managerial & 132 & 36.6 \\
\hline Supervisor or team leader & 46 & 12.7 \\
\hline Middle management & 95 & 26.3 \\
\hline Senior management & 50 & 13.9 \\
\hline Executive & 15 & 4.2 \\
\hline Not applicable & 23 & 6.4 \\
\hline
\end{tabular}

qualification. Job-level categorisation was altered to combine the categories of Middle Management with Supervisor or Team Leader to form one category labelled Middle Management, while Senior Management and Executive categories were collapsed into one job level.

\section{Statistical analysis}

The data obtained with Questionnaire 1 were analysed using descriptive statistics, while the data obtained from Questionnaire 2 were analysed using descriptive and inferential statistics, including $t$-tests and Analysis of Variance. The unidimensionality of the scale was also assessed. The data obtained from Questionnaire 3 were analysed using choice-based conjoint analysis. Individual part-worths were calculated based on Hierarchical Bayes modelling.

\section{Results \\ Questionnaire 2: Total Rewards Preference Questionnaire}

Principle Component Analysis (PCA) using Varimax, with Kaiser Normalisation rotation was used to establish the underlying factor structure of the scale, which was based on the WorldatWork Total Rewards model (2007). PCA is indicative of the construct validity of the measure (Hair, Babin, Money \& Samouel, 2003). Reliability was assessed using Cronbach's alpha and following the SPSS item analysis technique. The results obtained from the PCA suggested that the questionnaire was valid (factor loadings ranged from 0.669 to 0.872 ) and reliable (Cronbach's alphas ranged from 0.68 to 0.73 ).

Descriptive statistics were calculated based on the composite scores for the factors, based on the PCA-derived scale's measurement model. Figure 1 provides a graphical representation of the Means of the total reward elements for the various demographic groups. The results indicate that overall, Remuneration and Benefits were rated as the most important total reward elements in retention. Performance and recognition was rated second most important, although Baby Boomers rated this factor lower than other respondents. Work-life balance practices, Learning and Career advancement were rated similarly in overall preference while work-life balance climate was rated lowest overall in terms of its importance in retention.

\section{Differences between genders}

An independent-samples $t$-test revealed there was a statistically significant difference between men $(M=4.19$, $\mathrm{SD}=0.64)$ and women $[M=4.33, \mathrm{SD}=0.61 ; t(359)=2.18$, $p=0.02$, two tailed] for the measure of Learning and Career Advancement $(p<0.05)$, with women seemingly placing greater importance on this factor in their retention than men.

\section{Differences between race groups}

There was a statistically significant difference between white people $(M=4.13, \mathrm{SD}=0.64)$ and black people $[M=4.43, \mathrm{SD}=0.58 ; t(351)=4.55, p=0.00$, two tailed $]$ 


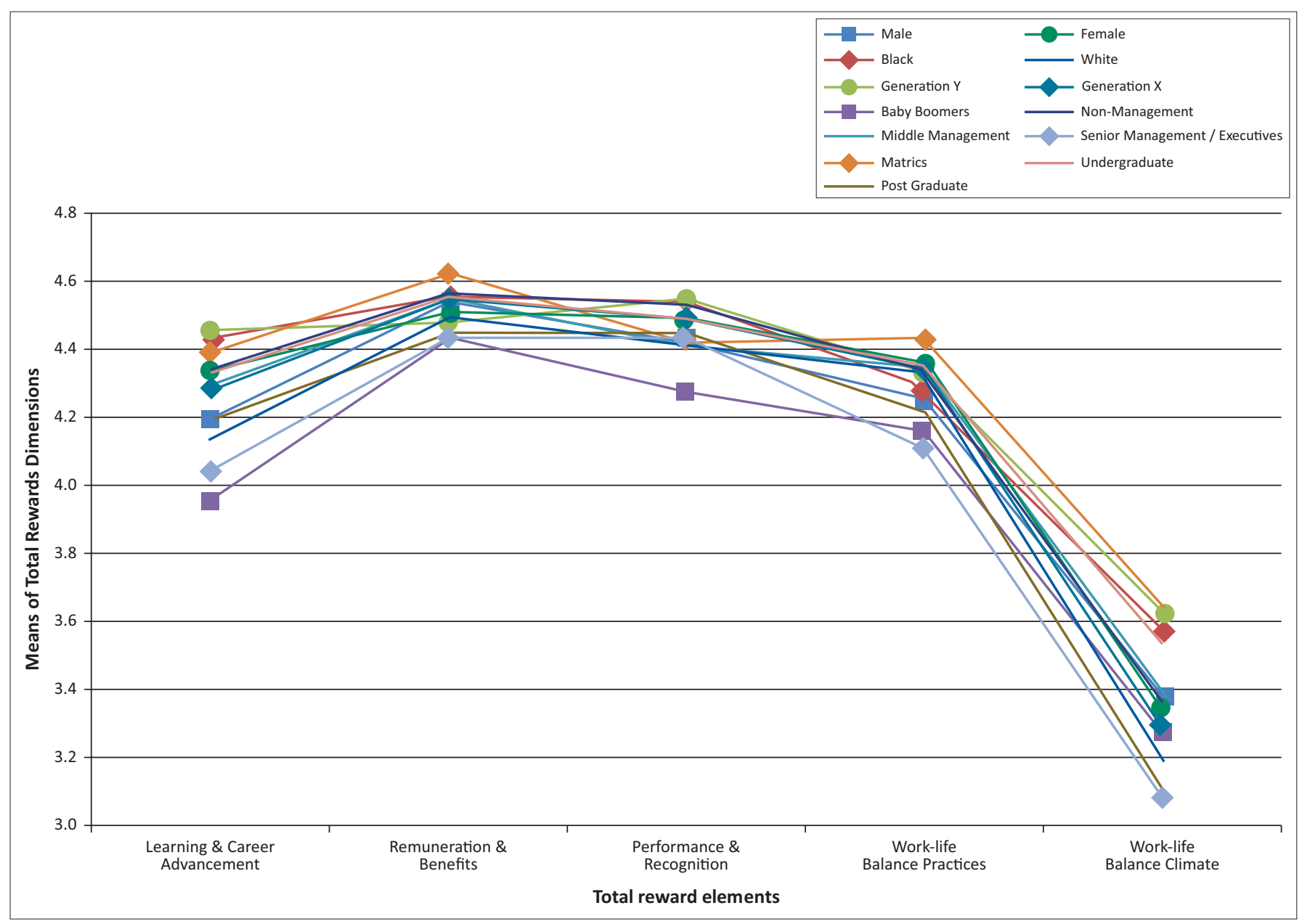

FIGURE 1: Comparison of the means of total rewards across demographic groups based on survey data.

for the Learning and Career advancement measure $(p<0.05)$ where black people considered this factor to be more important in their retention than white people. The second statistically significant difference that was noted between white people $(M=4.41, \mathrm{SD}=0.48)$ and black people $[M=4.54, \mathrm{SD}=0.46 ; t(351)=2.64, p=0.00]$ pertained to the measure of Performance and recognition $(p<0.05)$, where black employees considered this factor key in their retention. The third statistically significant difference was noted between white people $(M=3.19, \mathrm{SD}=0.94)$ and black people $[M=3.57, \mathrm{SD}=0.85 ; t(351)=3.94, p=0.00$, two tailed] for the measure of work-life balance climate $(p<0.05)$, where black people considered this factor to be more relevant in their retention than white people.

\section{Questionnaire 1: Remuneration Manager Questionnaire}

The results of Questionnaire 1 were used to design the conjoint tasks used in Questionnaire 3. The data were analysed by first focusing on the question with the highest percentage of responses under the category of Employee C and was eliminated and classified as level 3 in the conjoint task. The question with the highest percentage of responses for Employee B was then used to establish level 2 of the conjoint task, before being removed for further analysis.
The remaining questions with the highest percentage for Employee A were then translated into level 1 of the conjoint task. Where the results were equal across employees, a judgement was made as to whether the item should be classified as level 1,2 or 3. The final set of attributes and levels are indicated in Table 2.

\section{Questionnaire 3: Choice-Based Conjoint Task Questionnaire}

A method of assessing the reliability of a conjoint model is to determine the goodness-of-fit of the estimation model and is done by using the MultiNomial Logit model. For each iteration, the log-likelihood is reported together with a value of RLH (Root LikeliHood). This is a measure of how well the model fits the choice data, which means a respondent who answered inconsistently would have a low RLH value of 0.25 and the best possible value is 1.0 (Eggers, Farsky \& Gerber, 2009; Sawtooth Software, 2008). An RLH below 0.25 was reported for one respondent. All other respondents scored above this value, with 0.93 being the highest RLH value. This indicates that there was a high level of reliability for this model. The ratio of correctly predicted choices is called the hit rate, which is a common validity measure (Eggers et al., 2009; Schlechter et al., 2014). The hit rate for the conjoint model in this study 
TABLE 2: Relative importance of the attributes.

\begin{tabular}{|c|c|c|c|c|c|}
\hline Attribute & Level & Level description & Utility & $\begin{array}{l}\text { Relative importance } \\
\text { of attribute }(\%)\end{array}$ & Ranking \\
\hline \multirow[t]{3}{*}{ Learning } & 3 & On-the-job training & -153.17 & 9.1 & 5 \\
\hline & 2 & Tertiary Education Tuition Assistance & 9.76 & & \\
\hline & 1 & Leadership or management development programmes & 143.41 & & \\
\hline \multirow[t]{2}{*}{ Career advancement } & 3 & Promotion within current business unit or function & -132.94 & 10.3 & 4 \\
\hline & 2 & $\begin{array}{l}\text { Exposure to opportunities or projects outside of your current department or } \\
\text { business unit - may include overseas assignments }\end{array}$ & 203.03 & & \\
\hline \multirow[t]{3}{*}{ Remuneration } & 3 & Base salary targeting the middle of the market & -349.94 & 17.0 & 3 \\
\hline & 2 & Base salary targeting the upper end of the market & 147.46 & & \\
\hline & 1 & Base salary targeting the top end of the market and retention bonus & 202.48 & & \\
\hline \multirow[t]{3}{*}{ Benefits } & 3 & $0 \%$ Employer contribution to retirement fund plus basic medical cover & -679.13 & 35.2 & 1 \\
\hline & 2 & $\begin{array}{l}\text { Employer contributes } 50 \% \text { of total retirement fund contribution plus moderate } \\
\text { level of medical cover }\end{array}$ & 210.18 & & \\
\hline & 1 & $\begin{array}{l}\text { Employer contributes } 100 \% \text { of total retirement fund contribution plus highest } \\
\text { level of medical cover }\end{array}$ & 468.94 & & \\
\hline \multirow[t]{3}{*}{ Work-life balance } & 3 & Flexible work hours & 171.32 & 8.4 & 6 \\
\hline & 2 & Work from home & -101.70 & & \\
\hline & 1 & Reduced work schedule or work load & -69.61 & & \\
\hline \multirow{3}{*}{$\begin{array}{l}\text { Performance and } \\
\text { recognition }\end{array}$} & 3 & On-the-spot awards, for example, gift vouchers, verbal recognition & -355.00 & 20.0 & 2 \\
\hline & 2 & Short-term incentive linked to your performance & 58.28 & & \\
\hline & 1 & Short-term incentives linked to your performance plus stock options or shares & 296.71 & & \\
\hline
\end{tabular}

$n=368$.

was $38.5 \%$, which means that the model was able to produce $38.5 \%$ correct predictions from the holdout set. With four alternatives in the holdout set, a chance model would have resulted in $25 \%$ of predictions being correct (Schlechter et al., 2014). The hit rate for this study needs to be interpreted in the context of the holdout stimuli being developed on the basis of chance given that no previous research existed to guide the design of the stimuli. As such, a $38.5 \%$ hit rate is considered reasonable. As a second measure of validity, the absolute sum of differences between actual choice shares and predicted choice shares on an aggregated level were calculated, resulting in a Mean Absolute Error of prediction of 3.2\%. This indicates that deviation in the share prediction per alternative is very low and is considered satisfactory (Eggers et al., 2009). Based on this basket of evidence, it was concluded that the conjoint study was valid and reliable.

Derived utilities are used to calculate the relative importance of individual attributes. The range of utilities within each attribute was calculated using the difference between the highest and lowest utilities per attribute, divided by the sum of the ranges across all attributes. Each attribute's utility range is expressed as a percentage of the sum of the utility ranges across all attributes. These percentages provide an indication of the importance employees attach to the various total reward attributes in their ability to retain employees (Schlechter et al., 2014). Attributes with a larger range have a greater impact on the calculated utility values and are therefore deemed to be of greater importance. The part-worths and relative importance of the attributes that are based on these for the total sample $(n=368)$ are summarised in Table 2. Separate relative importance tables were then calculated for each of the demographic groups of employees. The results indicated a relatively consistent preference across all groups with respect to the ideal total rewards mix. Table 3 provides a summary of the ranked attributes per demographic group.

The conjoint task produced an ideal mix of total rewards, of which three reward elements were consistently classified as highly valued and important in the retention of employees. These were: Benefits, Performance and recognition, and Remuneration, respectively. Benefits were considered twice as important as Remuneration in deriving utility scores and preferences within the overall sample, as well as in all the demographic groups (Benefits $=35 \%$, Remuneration $=17 \%$ ). The highest level of Benefits, namely a 100\% employer contribution towards retirement funding, and the highest level of medical cover, were deemed most important in the retention of employees. These findings are consistent with the results of the WorldatWork Attraction and Retention survey (2007), whereby $90 \%$ of participants rated medical aid as having a moderate to high impact on retention.

Variations of the relative importance of attributes can be noted across demographic groups. Results for gender indicate that Benefits were considered to be important in retention for both men and women; however, the relative importance was greater for men $(37.1 \%)$ than for women (33.7\%), while Performance and recognition was deemed slightly more important for women (21.0\%) than for men (18.6\%).

Few differences were noted across different generation and race groups with all three groups indicating a preference for benefits, while Generation Y assigned a slightly lower level of importance to Remuneration (15\%) versus Generation X (17\%) and Baby Boomers (18\%). Generation Y also specified Work-life balance as being slightly more important $(12 \%)$ in their retention compared to Generation X (8\%) and Baby Boomers (7\%). 


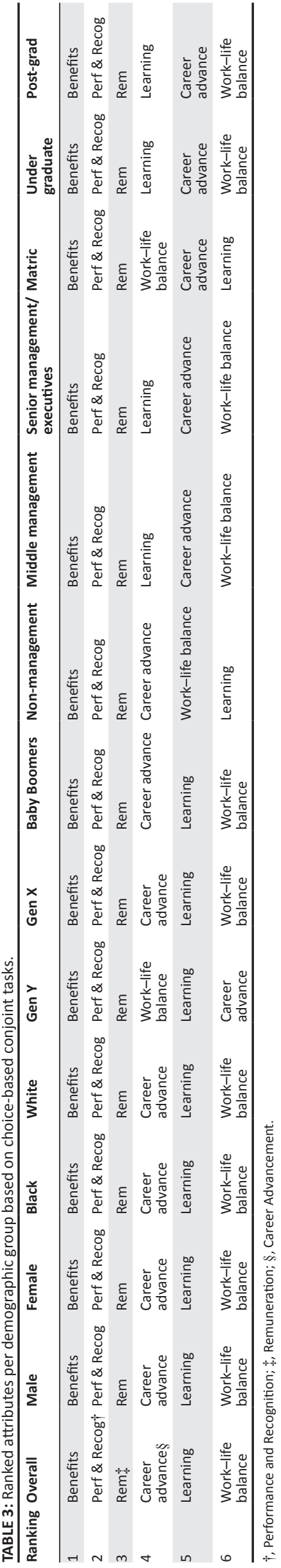

\section{Discussion}

The two main research objectives, firstly to develop a better understanding of the total reward preferences within a South African business context and secondly to identify the ideal or most desirable mix of total reward elements or total reward packages that would specifically retain employees from various demographic groupings, were investigated using both the conventional method of using a reward preference survey responded to on a Likert-type response scale as well as choicebased conjoint analysis (choice-based modelling). The latter method, which is novel in this field of the study more closely replicates real-life decision making in that individuals cannot obtain everything that they desire and have to psychologically make trade-offs between various combinations, unlike typical survey approaches where items are considered one at a time.

The results of the choice-based conjoint analysis revealed that all respondents considered financial rewards (Benefits, Performance and recognition, Remuneration, Career, respectively) as the most important component in their total rewards package that would lead to their retention. For most demographic groups, the remaining three places (ranked) were Career Advancement, Learning and Work-life balance. Work-life balance was found to be more important for Generation $\mathrm{Y}$ than career advancement. For those employees with only a matric qualification and those in non-managerial positions, access to learning opportunities were the least important in their retention.

Previous studies of total rewards that retain black employees in South Africa are limited. Benefits were consistently found to be the most important reward element in retention. Given the high cost of benefits such as medical aid, these are very important factors in retention, especially in South Africa, where a large portion of the population does not have access to benefits and public healthcare and social welfare pensions are inadequate. This sentiment was noted in a study carried out by Kochanski and Ledford (2001).

Baby Boomers, as the oldest generation and nearing retirement, valued retirement benefits, medical aid and base pay (Bussin, 2012; Tiku, 2007; Wallace, 2006). The current study corroborated these findings, as the highest level of benefits were the most valued reward element in the total rewards mix, followed by performance and recognition and remuneration. In South Africa, employees aged 50 and above are also likely to be the first generation who will be retiring out of a defined contribution plan as opposed to previous generations who received a pension from a defined benefit plan. Such arrangements have shifted the responsibility of retirement funding to the employee and subsequently heightened the awareness that employees have around the adequacy of their retirement funding.

Generation $X$ is retained by financial rewards such as base salary, medical aid and deferred compensation (Bussin, 2012). The current study supports these findings, as the highest level of benefits, performance, recognition and remuneration were 
deemed to be the most attractive elements in the reward mix and the most effective in the retention of these employees. Possible reasons for Generation X favouring these rewards could be attributed to this group's family focus, as they are likely to have young dependants for whom provision must be made in respect of medical aid. The current study further corroborates the findings of the Towers Perrin (2003) survey where base salary and variable pay were identified as factors that retained Generation Y employees (Bussin, 2012). Within the current study, performance and recognition (i.e. short-term incentives linked to your performance plus stock options or shares) and remuneration (i.e. base salary targeting the upper end of the market) were deemed important in Generation Y's retention. Unlike Baby Boomers and Generation X however, Generation Y selected the second level of the remuneration reward element which was comparatively lower than the first level selected by Baby Boomers and Generation X.

Benefits seem to retain Generation Y employees in the United States (Willmer, 2008). The current study supports these findings. The reason for this preference may be similar to that of the Generation Y employees in the United States who grew up in an environment where the U.S. healthcare system delivered fewer services at higher costs (Willmer, 2008). In South Africa, Generation Y employees are also likely to have been exposed to an inadequate public healthcare system and ever increasing health costs. Furthermore, the parents of Generation Y employees may have made inadequate provision for their retirement and not received a reasonable pension or, in some cases, received no pension and were dependent on social welfare. Such experiences may have heightened Generation $Y$ employees' awareness of the need to make adequate provision for their retirement, and for this reason, they may have an appreciation for the value of a company's contribution to benefits such as retirement funding and medical care.

For most demographic groups, the remaining three places (ranked) were Career advancement, Learning and Work-life balance. Work-life balance was found to be more important for Generation $\mathrm{Y}$ than career advancement. For those employees with only a matric qualification and those in nonmanagerial positions, access to learning opportunities was the least important in their retention. Other studies indicated that career advancement and opportunities formed a strong retention factor for all employee categories (Booysen, 2007; Khanyile \& Mapongo, 2007). Career advancement opportunities as well as work-life balance practices were noted in the literature as significant factors in the retention of female employees. Turnover among women was often related to salary inequities (Krishnan, 2009; McMullen, 2010; Sicherman, 1996; Stroh, Brett \& Reilley, 1996). Another study indicated that talent development and the prospects of better pay served as retention factors for women (Kotze \& Roodt, 2005). Findings from the current study partially support those of Sicherman (1996) and Kotze and Roodt (2005), as the highest levels of financial rewards, that is, Benefits, Remuneration, and Performance and recognition were all valued by women as part of their total rewards mix.
The findings of the current study did not support previous research, which indicated that Generation $X$ employees value work-life balances as a retention tool (Gabriel, 1999; Gursoy et al., 2008). The lowest level of work-life balance was selected by Generation X employees, while a greater level of importance was placed on career advancement and learning in determining the ideal total rewards mix. This could be because of the different method employed here, one where reward elements needed to be traded-off with one another. Generation Y employees on the other hand assigned more importance to non-financial factors such as Work-life balance in their total rewards mix. Work-life balance was deemed more attractive than career advancement in Generation Y's total rewards mix. This finding is supported by that of the 2005 South African Graduate Recruitment Association survey, which indicated that the youngest generation, namely Generation Y, was retained by career advancement opportunities, challenging assignments and work-life balance. Generation Y employees were retained by organisations that allowed them to be loyal to their lifestyle rather than their jobs (Roy, 2008; Ruch, 2000).

\section{Limitations and directions for future research}

The main limitation of this study is the issue of confounding variables. In particular, this refers to the current economic environment and associated factors, such as job stability. These factors are likely to have had a moderating effect on the results, as employees will elect rewards that meet basic physical and safety needs above esteem needs or selfactualisation needs (Robbins, Odendaal \& Roodt, 2001). The results may have been further influenced by the effects of the economic recession, as one of the organisations from which the largest proportion of the sample was drawn was undergoing an extensive retrenchment exercise at the time.

It is recommended that further research be conducted during a period of greater economic stability, as it is likely to produce different responses. Additional relevant factors were not taken into account. Future research might thus want to examine whether personality variables affect the relationship between rewards and employees' decisions to stay at the organisation.

\section{Conclusion}

The research confirms that rewards are important in every employment relationship. Offering customised reward packages that are fair, reasonable and regular can be an aid in the retention of talented employees. The overall ideal total reward mix includes financial and non-financial rewards when offered to employees in a manner that is reliable with preferences to gender, race and age cohorts. The results from the study can be used to guide the employer's reward strategy in their approaches of engaging or retaining their key employees.

\section{Acknowledgements Competing interests}

The authors declare that they have no financial or personal relationships that may have inappropriately influenced them in writing this article. 


\section{Authors' contributions}

The study was conducted by M.P. as part of her Masters in Organisational Psychology research project at the University of Cape Town. A.F.S. was supervisor for M.P. and M.H.R.B edited the work for publication.

\section{References}

Birt, M., Wallis, T., \& Winternitz, G. (2004). Talent retention in a changing workplace: An investigation of variables considered important to South African talent. South African Journal of Business Management, 35(2), 25-31.

Booysen, L. (2007). Barriers to employment equity implementation and retention of blacks in management in South Africa. South African Journal of Labour Relations, 31(1), 47-71.

Bussin, M. (2012). The Remuneration handbook for Africa: A practical and informative handbook for managing and recognition in Africa (2nd edn.). Randburg: Knowres Publishing.

Bussin, M., Nicholls, M., \& Nienaber, R. (2016). The relationship between occupational culture dimensions and reward preferences: A structural equation modelling approach. SA Journal of Human Resource Management/SA Tydskrif vir Menslikehulpbronbestuur, 14(1), a737. https://dx.doi.org/10.4102/sajhrm.v14i1.737

Bussin, M., \& Toerien, W.C. (2015). Influence of reward preferences in attracting, retaining, and motivating knowledge workers in South African information technology companies. Acta Commercii, 15(1), Art. \#290, 1-13. https://dx.doi. org/10.4102/ac.v15i1.290

Codrington, G. (2008, 10 May). Generation comparisons? @tomorrowtoday. Retrieved September 25, 2009, from https://www.tmtd.biz/2008/05/10/generationcomparisons/\#more-1562

Corporate Leadership Council. (2004). Retention drivers and strategies at employers of choice. Retrieved 15 July 2014, from https://www.clc.executiveboard.com

D’Amato, A., \& Herzfeldt, R. (2008). Learning orientation, organizational commitmen and talent retention across generations: A study of European managers. Journal of Managerial Psychology, 23(8), 929-953. https://dx.doi.org/10.1108/0268394081 0904402

De Vos, A., \& Meganck, A. (2008). What HR managers do versus what employees' value: Exploring both parties' views on retention management from psychological contract perspective. Personnel Review, 38(1), 45-60. https://dx. doi.org/10.1108/00483480910920705

Eggers, F., Farsky, M., \& Gerber, C. (2009). Monetary assessment of brand positioning Unpublished manuscript, University of Stellenbosch, South Africa.

Frank, F.D., Finnegan, R.P., \& Taylor, C.R. (2004). The race for talent: Retaining and engaging workers in the 21 st century. Human Resource Planning, 27(3), 12-25.

Gabriel, A.R. (1999). Retaining Gen Xers: Not such a mystery anymore. Commercial Law Bulletin, 14(4), 32

Gursoy, D., Maier, T.A., \& Chi, C.G. (2008). Generational differences: An examination of work values and generational gaps in the hospitality workforce. Internationa Journal of Hospitality Management, 27(3), 448-458. https://dx.doi.org/10.1016/j. ijhm.2007.11.002

Hair, J.F., Babin, B., Money, A.H., \& Samouel, P. (2003). Essentials of business research methods. Hoboken, NJ: Wiley.

Horwitz, F.M., Heng, C.T., \& Quazi, H.A. (2003). Finders keepers: What works best? Attracting, motivating and retaining knowledge workers. Human Resources ManagementJournal, 13(4), 23-45. https://dx.doi.org/10.1111/j.1748-8583.2003. tb00103.x

Horwitz, F.M., Heng, C.T., Quazi, H.A., Nonkwelo, C., Roditi, D., \& Van Eck, P. (2006) Human resource strategies for managing knowledge workers: An Afro-Asian comparative analysis. International Journal of Human Resource Management 17(5), 775-811. https://dx.doi.org/10.1080/09585190600640802

Jensen, D., McMullen, T., \& Stark, M. (2007). The Manager's guide to Rewards: What you need to know to get the best for - And from - Your employees. New York: Amacom.

Khanyile, N., \& Mapongo, R. (2007, June). The Rolling Stones-exploring the job hopping phenomenon among black professionals. Paper presented at the 28th SA Marketing Research Association Conference, Stellenbosch.

Kinnear, L., \& Sutherland, M. (2000). Determinants of organisational commitment amongst knowledge workers. South African Journal of Business Management, 31(3), 106.

Kochanski, J., \& Ledford, G. (2001). 'How to keep me' - Retaining technical professionals. Research Technology Management, 44(3), 31-38.

Kotze, K., \& Roodt, G. (2005). Factors that affect the retention of managerial and specialist staff: An exploratory study of an employee commitment model. South African Journal of Human Resources Management, 3(2), 48-55. https:// dx.doi.org/10.4102/sajhrm.v3i2.65
Krishnan, H.A. (2009). What causes turnover among women on top management teams? Journal of Business Research, 62, 1181-1186. https://dx.doi. org/10.1016/j.jbusres.2008.09.001

Maisela, J.M. (2001). Success factors for attracting and retaining highly skilled black professionals. Unpublished Master of Management research report, University of Witwatersrand, Johannesburg.

Masibigiri, V., \& Nienaber, H. (2011). Factors affecting the retention of Generation X public servants: An exploratory study. SA Journal of Human Resource Management 9(1), Art. \#318, 1-11. https://dx.doi.org/10.4102/sajhrm.v9i1.318

McMullen, T. (2010). Reward next practices. Philadelphia, PA: Hay Group. Retrieved February 21, 2014, from https://www.haygroup.com

Mmolaeng, M., \& Bussin, M. (2012). Drivers of public sector unions' wage demands in a low-inflation and recessionary environment in South Africa. South African Labour Relations, 36 (1), 1-17. https://hdl.handle.net/10520/EJC120857

Nzukuma, K. \& Bussin, M. (2011). Job hopping among Senior Black African managers in South Africa. South African Journal of Human Resource Management/ SA Tydskrif vir Menslikehulpbronbestuur, 9(1). Art \#360, 1-12. https://dx.doi.org/ 10.4102

Remchannel. (2007, November). South African Employee Benefits Guide [Survey]. Johannesburg: Remchannel.

Robbins, S.P., Odendaal, A., \& Roodt, G. (2001). Organisational behaviour. Global and Southern African perspectives (9th edn.). Cape Town: Pearson Education.

Roy, J.G. (2008). Ten tips for retaining the next generation. Utility Automation \& Engineering T\&D, 13(12), 8-11.

Ruch, W. (2000). How to keep gen $X$ employees from becoming X-employees, (cover story). Training \& Development, 54(4), 40.

Sawtooth Software, Technical Paper Series. (2008). CBC v6.0. Retrieved November 24 , 2014, from https://www.sawtoothsoftware.com/download/techpap/cbctech.pdf

Schlechter, A., Faught, C., \& Bussin. M. (2014). Total rewards: A study of artisan attraction and retention within a South African context. SA Journal of Human Resource Management/SA Tydskrif vir Menslikehulbron bestuur, 12(1), Art \# 648, 1-15. https://dx.doi.org/10.4102/sajhrm.v12i1.648

Sicherman, N. (1996). Gender differences in departures from a large firm. Industria and Labor Relations Review, 49(3), 484-505. https://dx.doi.org/10.1177/0019 79399604900307

Smit, W., Stanz, K., \& Bussin, M. (2015). Retention preferences and the relationship between total rewards, perceived organisational support and perceived supervisor support. SA Journal of Human Resource Management/SA Tydskrif vir Menslikehulpbronbestuur, 13(1), Art. \#665, 1-13. https://dx.doi.org/10.4102/ sajhrm.v13i1.665

Snelgar, R.J., Renard, M., \& Venter, D. (2013). An empirical study of the reward preferences of South African employees. SA Journal of Human Resource Management, 11(1), Art. \#351. https://dx.doi.org/10.4102/sajhrm.v11i1.351

South African Graduate Recruitment Association. (2005). Talent retention survey [Survey]. Cape Town: SAGEA.

Stroh, L.K., Brett, J.M., \& Reilley, A.H. (1996). Family structure, glass ceiling, and traditional explanations for differential rate of turnover of female and male managers. Journal of Vocational Behaviour, 49, 99-118. https://dx.doi. org/10.1006/jvbe.1996.0036

Sutherland, M.M. (2004). Factors affecting the retention of knowledge workers Unpublished Doctor in Commerce, Rand Afrikaans University, Johannesburg.

Temkin, S. (2008). Black women getting top management jobs. Business Day. Retrieved October 10, 2009, from https://www.businessday.co.za/Articles/Content. aspx?id $=57820$

Tiku, N. (2007, August). Boomer benefits: As workers retire, small companies face a talent crunch. Inc Magazine, pp. 44-46.

Towers Perrin. (2003). Working today: Understanding what drives employee engagement. Retrieved October 15, 2009, from https://www.towersperrin.com

Tucker, E., Kao, T., \& Verma, N. (2005). Next generation talent management: Insights on how workforce trends are changing the face of talent management. Retrieved June 06, 2013, from https://www.hewitt.com

Van Rooy, R., \& Bussin, M. (2014). Total rewards strategy for a multi-generationa workforce. SA Journal of Human Resource Management/SA Tydskrif vir Menslikehulpbronbestuur, 12, Art \# 606, 1-11. https://dx.doi.org/10.4102/ sajhrm.v12i1.606

Wallace, J.E. (2006). Work commitment in the legal profession: A study of Baby Boomers and Generation Xers. International Journal of the Legal Profession, 13(2), 137-151. https://dx.doi.org/10.1080/09695950600961293

Willmer, D. (2008). Gen 101: What you need to know about recruiting and retaining the workforce of tomorrow. Stellenbosch: OfficePro, Executive Edition, pp. 8-11.

WorldatWork. (2007). Attraction and retention: The impact and prevalence of worklife and benefit programs. Scottsdale, AZ: WorldatWork Press. 